This is a postprint deposited on EarthArXiv.

This article is published in 'Innovative Development of Agricultural Science and Education. World Experience and Current Priorities'. Materials of the Int'l Sci.-Pract. Conf. in Honor of the Year of Agriculture in the Rep. of Azerbaijan. Ganja, Azerbaijan. Azerbaijan State Agricultural University, Oct. 23-24, 2015. Ed. by N. Seyideliyev. Vol. 3. pp. 303-306. Conference Info: http://ispc2015.blogspot.com/

Aqrar elmin vo tohsilin innovativ inkişafi: dünya tocrübəsi vo müasir prioritetlor

\title{
EFFECTIVENESS OF THE GEOSPATIAL DATA PROCESSING AND USE OF THE STATISTICAL INFORMATION FOR PROPER ENVIRONMENTAL PLANNING AND ZONING: EXAMPLE OF THE ŠUMAVA NATIONAL PARK, CZECH REPUBLIC
}

\author{
Lemenkova P.A. \\ $\mathrm{PhD}$ Student at Univerzita Karlova v Praze, Př́rodovědecká fakulta, Prague, Czech Republic \\ E-mail: pauline.lemenkova@gmail.com
}

\begin{abstract}
Current paper details methodology and principles of the zoning and ranging of the nature reserve area of Šmava National Park (Czech Republic) aimed at the effective planning and monitoring special nature areas.Methodology includes complex geoecological assessment of the territory, GIS application and processing of statristical data. The specific case study includes unique nature area of the Šumava National Park located on the border terrotory Czech Republic-Germany. The methods used in this case study can be applied for similar research aimed at nature conservation and environmental audit.
\end{abstract}

Key words: ecological planning, GIS, environmental monitoring

Аннотация. В статье рассмотрены принщипь и методология ранжирования природоохранных регионов в пределах Шумавского Наџионального парка (Чехия) в иелях эффективного планирования и зонирования особо охраняемых территорий. Методология включает геоэкологическую комплексную оценку территории, использование ГИС и статистических данных. Методы оценки территорий уникального парка, расположенного на пограничной территории (Чехия-Германия) могут быть использованы при аналогичных работах в природоохранных аналитических работах по ресурсосберегающему аудиту.

Ключевые слова: экологическое планирование, ГИС, природоохранный мониторинг

Current study area is located in the Šumava National Park (ŠNP), Czech Republic (Fig.1). Zoning the NP is a necessary environmental activity aimed to restore the ecological stability of the landscapes adapted to each specific type of landscape development and anthropogenic modification. Since 1990 the ŠNP has been the protected Biospherical Reserve of UNESCO [1].

Just upon its foundation in 1991, the zonation of ŠNP was primarily based on the internationally accepted principles and methodology. However, change in governance of the national park in 1995 necessarily caused change in management as well. Besides that, there are changes in the landscapes caused by various reasons, both anthropogenic and natural ones [8]. These include among others significant changes in plant species diversity as well as shifts of dominance among certain species caused by modifications in the environmental treatments [7].

Fig.1. Satellite map of the Šumava National Park and surroundings. Source: Engleder, 2007

Without proper environmental management, populations of the species within the ŠNP are not able to survive: the extinction of the flowers population is inevitable within several decades. Actual methodology of the zonation of the ŠNP is well described [6] where detailed principles and history of the sub-divisions of ŠNP are given. The vegetation zones in the ŠNP include: fir-beech and spruce fir-beech, secondary grasslands and heath, scrub, forests, water habitats (e.g. streams, lakes, springs and wetlands with coastal vegetation), bogs, rocks at various geomorphic forms, debris, and finally, habitats modified or affected by man [3]. The ŠNP belongs to the Bohemian Forest which is divided between two national parks: the one in Czech Republic and another

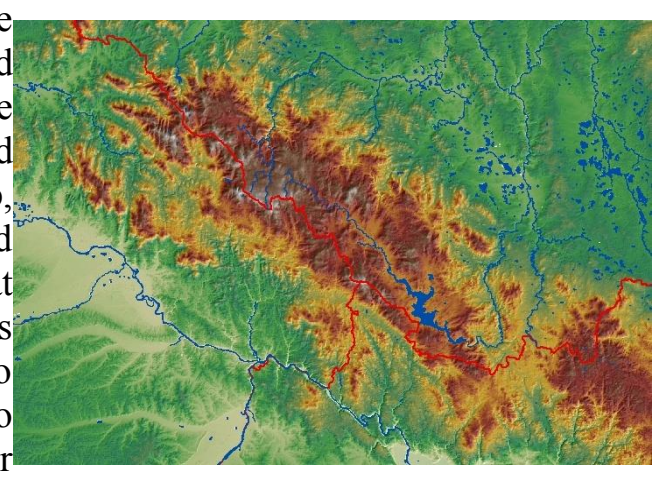


in Germany [4]. The area is represented by the vast wooded areas, precious mountain spruce and protected mixed forests of various ages, peat bogs, meadows biotops. Altogether, they create a unique mosaic of biotopes, which encompass a variety of rare, endemic and endangered species.

Nowadays, the geographic zoning of the ŠNP includes following ecological areas (Fig.2), defined according to the regulation of the category "National Park" by the Government of Czech Republic 163/1991 Sb and the Act on the Protection of Nature and Landscape No. 114/92 Coll (Ochrana území): Thus, since 1991 via 1995 and up to now, the zonation of ŠNP undergone changes, which resulted in the significant (almost double) decrease of Zone I (strictly conserved), slight increase of Zone II and increase of Zone III as well [6].

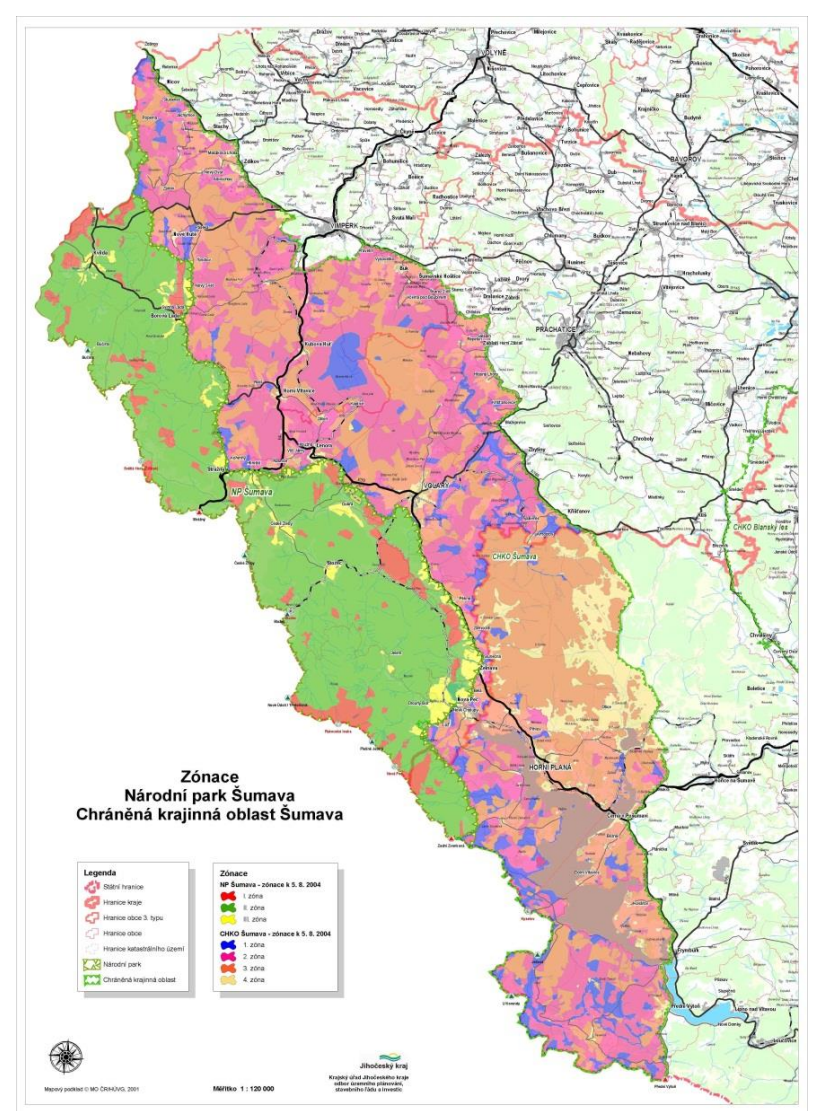

Fig.2. Zonation of the ŠNP. Source: Mapový podklad MO CR/HUVG, 2001.

Zone I: strictly protected nature. It includes the most valuable and the most stable areas with natural ecosystems (the remains of primeval forests), wetlands and upland peat. Zone I is only allowed for the natural development and any human interaction is prohibited. The area of Zone I includes a high concentration of natural values and most valuable parts of the ŠNP. The basic yet important components of Zone I include following components: spruce forests, beech forests, raised bogs, springs, fens and transitional mires, other valuable NATURA 2000 habitats. The fauna species include protected important examples, e.g. lynx, otter and peregrine [2]. The total area of forest in Zone I is 18,233 ha and of deforested areas 1,202 ha, which make $28.4 \%$ of the area of the ŠNP [6].

Zone II: controlled nature, dominant type for the ŠNP. It includes the majority of the remaining forest and other ecosystems with various types of vegetation composition and conditions. Zone II includes natural areas that were variously influenced by human activities previously, and which now require active management [6]. The aim of all activities in Zone II is to maintain the natural balance and the gradual approximation of the existing ecosystems (through streamlining and reconstruction) towards natural communities. The environmental sustainability is highly important in the area of Sumava [5]. 
Zone III: a boundary zone. It includes the human affected areas: e.g., urban villages and adjacent non- forest areas, where the main habitats are heavily modified and altered by human activities. The core area of Zone III contains built-up areas and areas that might become built-up ones. The protection aim at this area is to maintain and promote the use of this area for the permanent housing, services, agriculture, tourism and recreation, provided it does not conflict with the sustainable development of the ecosystems.

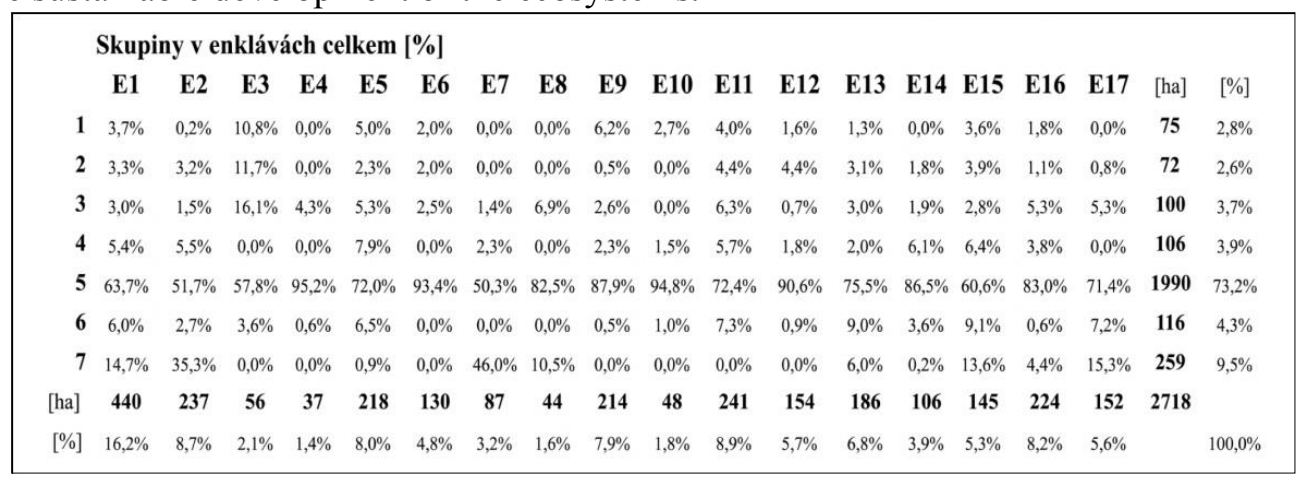

Table I. Groups enclaves in total [\%]

The research included processing of statistical and cartographic sources for assessment of terrirory. The data used in the current research included several various sources.

A. GIS layers used for the spatial analysis include various vector layers in ArcGIS shapefile (.shp) format. The data were stored in a GIS Project with the following coordinate system and mathematic projects data: World Geodetic System WGS 84, ellipsoid Bessels, Křovák's Projection with two pseudo standard parallels, which is an oblique case of the Lambert conformal conic projection designed in 1922 for C/zech Republic. Among many basic layers (e.g. hydrological network, municipalities and cities, roads, borders), geographic sources were used as a core and most important sources of information, e.g. NATURA 2000 vector layer which contains information on representatives of species covering habitats of study area in the attribute table.

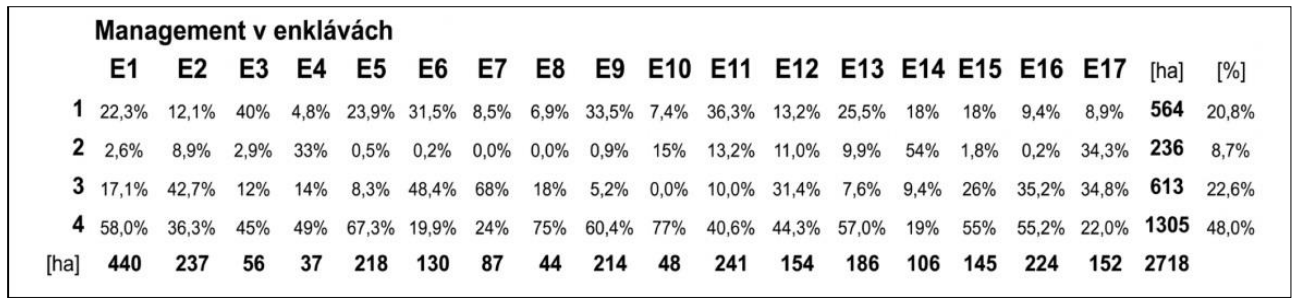

Table II. Management in enclaves, ha, \%

B. Tables containing statistical data (Tables I and II) and attribute tables available for GIS layers contains information: spatial, ID information and metadata.

C. Additional materials: maps and descriptions of the selected study areas.

The GIS project has been performed in Quantum GIS (QGIS) software, an open source GIS. It has large possibilities on spatial analysis due to the embedded numerous plugins with geospatial analysis functions, compatibility with ArcGIS layers (.shp-files) as well as other formats and geospatial standards. At the beginning of the project layers were collected in the working folder, visualized and inspected. Then, some of the layers were adjusted to the study area (territory of ŠNP) via "Clip"- function from the "Vector/Geoprocessing Tools" menu, which enables to cut off the exact area from the unnecessary parts and to standardize the common borders of the study area (e.g. the layer 'Natura-2000' which previously encompassed larger areas than ŠNP). The information stored in the NATURA 2000 vector layer was studied on the species that dominate within habitats of study area. These data were inspected in the attribute table (e.g., Picea abies (Norway spruce), Abies alba (Silver fir) do 5\%, zbytek Picea abies, v podrostu ojedinýle Soldanella montana (snowbell), Huperzia selago, Betula pendula (Silver birch), Salix aurita (eared willow), Filipendula ulmaria (meadowsweet), Equiseto-Piceetum, Picea abies, 
Vaccinium myrtillus, Sphagnum sp., Equisetum sylvaticum, Dryopteris dilatata, Piceo-Alnetum, Alnus incana, Picea abies, Pinus sylvestris, Betula pendula, Caltha palustris, Chaerophyllum hirsutum, Viola palustris, Molinia caerulea, Viola palustris, Taphroseris crispa, Valeriana dioica, Carex brizoides). For inspection of these values the relevant column from the attribute table was imported using "List unique values" function from the "Vector/Analysis Tools" menu of QGIS. The layer "Spruce" contains information on various types of spruce that cover study area and data on its characteristics: length, growth, age, unique ID, size of coverage, codes, shape and length of area. The map layouts have been prepared using "Composer Manager" function of the QGIS menu. Geospatial research for correct environmental zoning and assessment has actual and ongoing need to obtain data, analyze statistics and process remote sensing information, especially for the purpose of ecological monitoring, geobotanical investigations, spatial mapping, planning and assessment.

This paper aimed to demonstrate actuality and effectiveness of the Earth observation data for the proper management of the environmentally protected areas, such as national parks. Processing and timely feedback of all kinds of changes in the land cover types requires obtaining actual data and geoinformation to correctly guide environmental management and perform changes in zoning. The GIS visualization technologies are used to effectively process, synchronize and combine multiple source data. The applications of GIS to the analysis and processing of ecological geobotanical data improves management of various geospatial data for the staff working at national parks. It furthermore promotes the effectiveness of the geospatial research as applied towards visualization and assessment of the environmentally protected areas. Given example of the data management in the Šumava National Park located in Czech Republic can nevertheless be applied to other national parks and botanical reserves located elsewhere. The paper contributes towards the development of computerized monitoring, assessment, planning and zoning of national parks.

\section{Literature:}

[1] Bilek M., Kalal J., Bilek J. 1990. South Bohemia and Bohemian Forests information system (Spolek pro popularizaci jižních Čech). Šumava.

[2] Bláha J., Romportl D. and Křenová Z. (2013) Can Natura 2000 mapping be used to zone the Sumava National Park? European Journal of Environmental Sciences, Vol. 3 (1), pp. $57-$ 64.

[3] Bucharová A., Brabec J., Münzbergová Z. 2012. Effect of land use and climate change on the future fate of populations of an endemic species in central Europe. Biological Conservation $145,39-47$.

[4] Chabera S. 1998. Fyzický zeměpis jižních Čech. Přehled geologie, geomorfologie, horopisu a vodopisu. Jihočeská univerzita, České Budějovice. $139 \mathrm{~s}$.

[5] Cudlinová E., Lapka M., Bartos M. 1999. Problems of agriculture and landscape management as perceived by farmers of the Šumava Mountains (Czech Republic). Landscape and Urban Planning 46, 71-82.

[6] Křenová Z. and Hruska J. (2012) Proper zonation-an essential tool for the future conservation of the Sumava National Park. European Journal of Environmental Sciences, 62(2), №1

[7] Mašková Z., Dolezal J., Kvet J., Zemek F. 2009. Long-term functioning of a speciesrich mountain meadow under different management regimes. Agriculture, Ecosystems and Environment 132, 192-202.

[8] Prach K., Bufková I., Zemek F., Herman M., Masková Z. 2000. Grassland vegetation in the former military area Dobra Voda, the Sumava National Park. Silva Gavreta 5, 101-112. 